\title{
Sero prevalence of Hepatitis B Virus (HBV) in general population of Lakki Marwat, Khyber Pakhtunkhwa- Pakistan
}

\author{
Muhammad Ishaq Shah ${ }^{1}$ and Zia Ur Rahman Awan ${ }^{2 *}$ \\ 1. Department of Molecular Biology, Faculty of Science and Technology, Virtual University Lahore-Pakistan \\ 2. Microbiology and Biotechnology Laboratory, Department of Zoology, Govt. Post-Graduate College Bannu- \\ Pakistan \\ *Corresponding author's email: ziabiotech78@yahoo.com \\ Citation \\ Muhammad Ishaq Shah and Zia Ur Rahman Awan. Sero prevalence of Hepatitis B Virus (HBV) in general \\ population of Lakki Marwat, Khyber Pakhtunkhwa-Pakistan. Pure and Applied Biology. Vol. 9, Issue 4, \\ pp2511-2520. http://dx.doi.org/10.19045/bspab.2020.90267
}

\begin{tabular}{|c|c|c|c|}
\hline Received: $16 / 04 / 2020$ & Revised: 01/07/2020 & Accepted: 06/07/2020 & Online First: 06/08/2020 \\
\hline
\end{tabular}

\section{Abstract}

A research study was conducted with the aim to investigate the frequency of Hepatitis B Virus positivity in the general population of district Lakki Marwat. Blood samples were collected from 2000 individuals in various hospitals and diagnostic/ medical laboratories of the study area. All the blood samples were evaluated for HBV by Liver function tests (LFTs), Immunochromatographic tests (ICT) and PCR. Among the total, 108 blood samples were found positive for the virus with a prevalence rate of $5.4 \%$. A higher prevalence rate $(4.15 \%)$ was found in males as compare to $1.25 \%$ in females. Among the total HBV positive samples $83(76.85 \%)$ were male (from 4 years to 75 years) and 25 (23.19\%) were female (from 5 years to 60 years). The HBV positive data was also analyzed for various age groups i.e. 1-15 years, 16-30 years, 31-45 years, 46-60 years and above 60 years. It was found that disease prevails more in males than in females and is predominant in the age group 16-30 (57\%), followed by age groups 31$45(23 \%), 1-15(10.18 \%), 46-60(7 \%)$ and $>60(3 \%)$ respectively. Various risk factors were found involved in the spread of HBV in the study area like medical injections (59.26\%), dental procedures by medical quacks (12.04\%), hair dressing and shaving salons/ barber shops $(11.11 \%)$, transfusion of blood and blood based products $(5.56 \%)$, mother to children transmission (3.70\%), occupational risk groups (2.78\%), sexual transmission (2.78\%), tattooing $(0.92 \%)$, circumcision $(0.92 \%)$ and shared injection by drug abuser $(0.92 \%)$.

Keywords: Frequency; HBV; ICT; PCR; Risk factors

\section{Introduction}

Hepatitis which literally means inflammation of the liver; is caused by six different types of viruses, which are hepatitis A virus (HAV), hepatitis B virus (HBV), hepatitis $\mathrm{C}$ virus (HCV), hepatitis $\mathrm{D}$ virus (HDV), hepatitis $\mathrm{E}$ virus (HEV) and hepatitis $\mathrm{G}$ virus (HGV). These viruses are very distinct from each other and the similarities exist only in their organ specificity and epidemiology. Hepatitis A and hepatitis $E$ viruses cause water and food borne diseases while hepatitis $\mathrm{B}$, hepatitis $\mathrm{C}$, hepatitis D and hepatitis $\mathrm{G}$ viruses cause blood-borne diseases [1,2].

Various dreadful diseases like chronic hepatitis, hepatic liver cirrhosis (HLC) and hepatocellular carcinoma (HCC) are caused 
by Hepatitis B Virus (HBV) of the family hepadnaviridae. The virus has a circular partially double stranded DNA genome [3]. The virus infects about 400 million people from all around the world with majority (75\%) patients from Southeast Asia and Fareast Asia, where it causes one million per annum deaths [4]. There are reservations and uncertainties about the HBV origin and its association with humans. Relationship of HBV with humans started some 33600 years ago [5]. In another work, the researchers sequenced the avian hepadna virus in Zebra finches and claimed that viruses of the Hepadnaviridae evolved some 40-80 million years ago [6]. On May 2018, Barbara Mühlemann and others reported that they have discovered ancient hepatitis $B$ virus in 4,500 years old human remains. They analyzed 12 ancient HBV genomes that were obtained from 800 to 4,500 years old human remains from Europe and Asia. According to them the HBV association with humans started some 8.6 to 20.9 thousand years ago [7]. In another study the complete genome sequence of HBV from an Italian child mummy of mid $16^{\text {th }}$ century was recovered [8].

Ten genotypes of hepatitis B exist, which are represented by capital letters from A-J [9]. The most common HBV genotype in Pakistan is genotype D $[10,11]$ and the common type in Khyber Pakhtunkhwa province is genotype A [12]. A study conducted on healthy blood donors at Kurram Agency reported 5.07\% HBV prevalence rate in the area. The study unveiled that in Pakistan patients of hepatitis B are handled without taking virus genotypes in consideration during treatment and this misinterpretation is leading to new mutant strains emergence and drug resistance [13]. Pakistan is the world $5^{\text {th }}$ largest populous country and hosts 207.77 million people [14] but due to low health standards, Human Development Index of the United Nations ranks Pakistan in $147^{\text {th }}$ position amongst 188 countries [15]. Seven to Nine million carriers of hepatitis B, places Pakistan in the list of most HBV contaminated countries with a 3$5 \%$ carrier rate [10].

Dr. Baruch S Blumberg, a Nobel laureate discovered the causative agent of hepatitis B [16]. During investigation Dr. Blumberg with his colleagues found a distinct protein in the liver cells of an Australian Aboriginal man, hence they called it an Australian antigen and then a Hepatitis B surface antigen (HBsAg). They speculated that this protein might be the causative agent of hepatitis B and if inoculated, could be used to evoke an immune response. The hypothesis was proven true. First hepatitis $B$ vaccine was made by Dr. Blumberg and Dr. Irving Millman in 1969 [16-18].

Pakistan had a very high rate of $22.48 \%$ of acute hepatitis B in children and the reasons of such a high endemicity are immunization $\&$ prevention unawareness and transfusion of infected blood [19]. The subjects of chronic liver diseases and hepatitis $\mathrm{C}$ are also co-infected with hepatitis $\mathrm{B}$ virus and the estimation of such co-infection is up to $60 \%$. In view of the above genuine facts, the current study was conducted to know about the seroprevalence of hepatitis B in the study area [20].

\section{Materials and methods Study area}

District Lakki Marwat lies in the southern part of Khyber Pakhtunkhwa Province, 171.2 meter (565 feet) above sea level between $32^{\circ} / 17^{\prime}$ to $32^{\circ} / 53^{\prime} \mathrm{N}$ latitudes and $70^{\circ} / 23^{\prime}$ to $71^{\circ} / 16^{\prime} \mathrm{E}$ longitudes. The neighboring districts of the study area are Bannu and Karak on its northern, Mianwali on eastern, D.I.Khan on the south-eastern and Tank and South Waziristan on the western side [21]. According to the Census report 1998, the total population of Lakki Marwat district was 490025 [22]. Recent Census report of 2017 shows that its population comprises of 876182 individuals, in which 441816 are males and 434357 are females. The ratio of urban and rural population is $12 \%$ and $88 \%$ respectively [23]. 


\section{Data collection}

A $3 \mathrm{ml}$ venous blood sample was collected from each of 2000 individuals who came to visit the hospitals and diagnostic/ medical laboratories of the district Lakki Marwat for various purposes. Blood sample was collected after taking their consensuses. The blood samples were accumulated in small veils having anticoagulant EDTA and were labeled with natural numbers. Basic information like name, father's name/ husband name, sex, age, contact number and locality against each number was recorded on separate sheet. For sera separation, the samples were centrifuged at $5000 \mathrm{rpm}$ for 15 minutes.

\section{Screening of samples}

Liver Function Tests were performed on all blood samples and HBV positive blood samples were tested by Immunochromatography tests and then by PCR for confirmation of hepatitis B infection.

\section{Bio-chemical diagnosis}

The Liver Function Tests (LFTs) especially ALT (Alanine Aminotransferase Test) and AST (Aspartate Aminotranferase Test) were performed by using Microlab 300 (Merck, USA), ALT and AST kit (Diasys Diagnostic System Germany).

\section{Immuno-chromatography tests (ICT)}

Immuno-Chromatography Tests were performed for confirmation of HBsAg in the HBV patients. InTec (China) and Determine (Abbot) ICT kits were used. The reason for using these kits was their coast effectiveness and 98\% sensitivity [24].

\section{HBV-DNA detection by PCR}

The ICT positive blood samples were confirmed by PCR.

\section{Data analysis}

Data was analyzed by using SPSS software for windows. Results were expressed in percentage.

A survey was carried out with the aim to determine the HBV prevalence in the general population of district Lakki Marwat and also to know about the various risk factors responsible for transmission of HBV in the study area. Blood samples were collected from 2000 individuals (both healthy and diseased) who came to visit the DHQ Hospital Lakki Marwat, City Hospital Lakki Marwat and Tehsil Headquarter Hospital Serai Naurang and various medical/diagnostic laboratories of the district viz. Advanced Medical Laboratory Lakki Marwat, Shafiullah Clinical Lab Lakki Marwat, City Medical Lab Lakki Marwat, Peshawar Medical Lab Serai Naurang, Khyber Medical Lab Serai Naurang and Sarhad Medical Laboratory Serai Naurang. All blood samples were tested by Liver Function Tests (LFTs), and then by Immuno-chromatography tests (ICTs). For further conformation the positive blood samples were evaluated by PCR and 108 blood samples were found HBV positive ultimately with a prevalence rate of $5.4 \%$ in the general population of the study area (Table 1).

Among the total HBV positive samples 83 individuals $(76.85 \%)$ were male (4 years to 75 years) and 25 individuals $(23.19 \%)$ were female (5 years to 60 years). The occurrence of disease in males was found $4.15 \%$ and in females it was quite low i.e. $1.25 \%$. The HBV positive data was also analyzed for various age groups i.e. 1-15 years, 16-30 years, 31-45 years, 46-60 years and more than 60 years. It was found that disease is more prevalent in males than in females and predominated in age group $16-30(57.41 \%)$, followed by age groups $31-45$ (23.15\%), 1-15 (10.18\%), 46-60 $(6.5 \%)$, and $>60(2.8 \%)$ respectively (Table $2)$.

To know about the risk factors the patients above age 16 years were investigated that "what would be the possible reason to get this disease in their view?" The above said question was asked from the parents of kids ( $\leq 15$ years of age). Their responses were analyzed and it was found that medical injections (59.26\%), dental procedures $(12.04 \%)$, hair dressing \& shaving in barber shops $(11.11 \%)$ and transfusion of blood \& blood based products $(5.56 \%)$ are the major risk factors of HBV spread in the study area while mother to children transmission (3.07\%), occupational risk groups (2.78\%), 
sexual transmission $(2.78 \%)$, Circumcision $(0.92 \%)$, Tattooing $(0.92 \%)$ and injecting abused drugs $(0.92 \%)$ are least significant risk factors (Table 3 ).

Table 1. Sero prevalence of HBV in Lakki Marwat $(n=2000)$

\begin{tabular}{|l|c|c|}
\hline Population under study & Results & \% age \\
\hline Number of HBV positive individuals by LFTs & 182 & 9.1 \\
\hline Number of HBV positive individuals by ICTs & 133 & 6.65 \\
\hline Total number of HBV positive individuals by PCR & 108 & 5.4 \\
\hline Number of HBV positive individuals by PCR (Male) & 83 & 4.15 \\
\hline Number of HBV positive individuals by PCR (Female) & 25 & 1.25 \\
\hline
\end{tabular}

Table 2. Age wise prevalence of HBV in Lakki Marwat

\begin{tabular}{|c|c|c|c|c|c|}
\hline S/N & Age groups (Years) & Male Subjects & Female Subjects & Total & \%age \\
\hline $\mathbf{1}$ & $1-15$ & 7 & 4 & 11 & 10.18 \\
\hline $\mathbf{2}$ & $16-30$ & 51 & 11 & 62 & 57.41 \\
\hline $\mathbf{3}$ & $31-45$ & 19 & 6 & 25 & 23.15 \\
\hline $\mathbf{4}$ & $46-60$ & 3 & 4 & 7 & 6.5 \\
\hline $\mathbf{5}$ & $>60$ & 3 & 0 & 3 & 2.8 \\
\hline
\end{tabular}

Table 3. Risk Factors of HBV in district Lakki Marwat

\begin{tabular}{|c|l|c|c|}
\hline S/N & Possible Risk Factor & $\begin{array}{c}\text { No. of } \\
\text { Individuals }\end{array}$ & $\begin{array}{c}\text { Percentage } \\
(\%)\end{array}$ \\
\hline 1 & Medical Injections & 64 & 59.26 \\
\hline 2 & Dental Surgery & 13 & 12.04 \\
\hline 3 & Barber Shops & 12 & 11.11 \\
\hline 4 & Blood and Blood based Products transmission & 06 & 5.56 \\
\hline 5 & Mother to Children and Intra-familial transmission & 04 & 3.70 \\
\hline 6 & Occupational Risk Groups & 03 & 2.78 \\
\hline 7 & Sexual Transmission & 03 & 2.78 \\
\hline 8 & Tattooing & 01 & 0.92 \\
\hline 9 & Injections Drug Users & 01 & 0.92 \\
\hline 10 & Circumcision & 01 & 0.92 \\
\hline
\end{tabular}

\section{Discussion}

The hepatitis B virus prevalence in Pakistan shows great diversity within and among its various provinces/regions due to its multicultural and multi-ethnical populations. There is great difference in the result of studies conducted on rural and urban population and in various professional and socioeconomic groups. Pakistan is considered as intermediate to highly endemic region for HBV. The current study revealed a higher $\mathrm{HBV}$ prevalence in male individuals than in females $(4.14 \%$ vs. $1.25 \%)$ and same results have been reported by various researchers of the country [25-33]. The reason of higher prevalence may be the fact that males get more exposure to the risk factors than females [29]. In the present study the highest prevalence of disease was observed in age groups 16-30 (years), which coincides the work of many scientists $[29,32,34,35]$. Similarly the age group 31-45 (years) was also found susceptible to HBV infection and the findings of various researchers $[25,26,29$, $31,36,37]$ verify the author's work. Many scientists $[26,29,31,35]$ found that hepatitis B infection is least frequent in age group above 60 years and the present study endorsed their results.

The prevalence rate of hepatitis B virus in the inhabitants of district Lakki Marwat during study period was found $5.4 \%$. Prior to the current work, another study conducted at DHQ hospital, Lakki Marwat 
on OPD patients showed a very high hepatitis B prevalence rate of $12.12 \%$ [37]. The higher prevalence may be due to the fact that they have targeted only a specific group or it means that the disease has been decreased since 2012 due to vaccination and awareness campaigns. Various regions/ districts of Khyber Pakhtunkhwa exhibit divergent results regarding $\mathrm{HBV}$ prevalence. In the districts of Dir and Charsadda, its prevalence was found $2.6 \%$ $[30,34]$. In district Swat it was 3.5\% [38]. The HBV prevalence in the general population of neighbor districts of Lakki Marwat is, $16.06 \%$ in Dera Ismail Khan [39] and $1.93 \%$ in Bannu [40]. In antiterrorism war stricken areas, there was relatively very high prevalence rate of the disease i.e. $21.5 \%$ in the IDPs of Malakand, $14.9 \%$ in inhabitants of Kurram agency, $10.33 \%$ in the IDPs of South Waziristan region and $07 \%$ in the IDPs of North Waziristan and Bakakhel [28, 32, 35, 41]. The reason of relatively high prevalence of disease in the general population of district Lakki Marwat than Dir, Charsadda and Swat districts may be due to the fact that the study area is a suburb of war stricken areas which show a higher prevalence. Hepatitis $B$ victimizes the individuals of rural area 3.8 times more than urban areas and similarly the disease is 2.2 times more prevalent in the individuals with poor economic conditions. Since the study area fulfills both the conditions, therefore it might be the reason of relatively higher HBV prevalence in the area [25].

Hepatitis B Virus spreads by vertical and horizontal transmissions. Vertical transmission means transfer of HBV from mother to her children while horizontal transmission means proliferation of disease by body fluids (blood and lymph etc). Various risk factors prevailed in the study areas are following.

\section{Medical injection}

It is the one of the major risk factor of HBV spread in the area. Patients usually prefer injectable over oral medicines because they consider them quick relief provider. The use of medical injections is very common practice in the district, especially in the rural area, where people usually consult medical quacksalvers. These quacksalvers use contaminated needles and they use the same syringe to give many injections to different patients. Due to low literacy rate the patients are unaware of the fact that these contaminated injections are the major source of HBV transmission. Some authors consider the use of medical injections as a potential threat of hepatitis B in Pakistan $[42,43]$.

\section{Dental surgery}

Dental treatment demands a great care and hygiene. Since qualified dentists and oral surgeons claim high charges, so people prefer to take services from dental quacks with unsterilized equipment which may cause dreadful diseases like hepatitis B [44, 45].

\section{Barber shops}

At the barber shops, the procedures of work are not safe. They do not use disposable razors/ blades rather use the same razor/ blade to shave many customers. HBV infected razor may transmit this virus to others [46].

\section{Transfusion of blood and blood based products}

Blood banks usually acquire blood from paid blood donors and amongst them many are drug abusers. Drug abusers are mostly hepatitis patients and hence may be a potential source of the disease $[47,48]$.

\section{Mother to child and intra-familial transmission}

Vertical transmission of HBV from infected mother to her children is a wellknown route of hepatitis $B$ transmission [49]. Transmission of the virus among family members is also a potential source of the disease $[50,51]$. Due to low literacy rate and prevailing poverty in the area, people do not take necessary steps to avoid this disease.

\section{Sexual transmission}

As HBV is found in body fluids (blood and semen etc) so it transmits from one partner to the others during sexual process [52-55]. 
Inhabitants of the area usually do not follow the precautionary measurement even when they come to know that the other partner is HBV positive and hence this risk factor prevails significantly in the district.

\section{Occupational risks}

Professionals of health services, prostitution, and haircutting and shaving are at greater risk of catching HBV than general population [54, 56-61]. A study conducted on 75 health care workers of three major hospitals of the KP province and reported a $2.18 \%$ hepatitis $B$ prevalence rate [62]. In another report [63] $11.65 \%$ occurrence rate of $\mathrm{HBV}$ in the female sex workers of Lahore was observed.

\section{Tattooing}

To express love and affection with someone many youngster of the district make tattoos. They imprint the names of their special one, shapes of heart or alphabet letters of their beloved on their hands and arms. Many females of the district tattoo a traditional green, blue or black spots (called Khaal) on chins, foreheads and between the eye brows. Tattoo making is also a potential source of HBV [64-66]. So precautions and safety measurements are vital to avoid the cruel clutches of hepatitis B.

\section{Circumcision}

In the rural areas of the district circumcision is mostly done by local barbers and medical quacks. People prefer them due to easy access and low fee. This is also a contributor of HBV spread in children. Different studies also reconcile the HBV transmission by this procedure $[67,68]$.

\section{Injection drug users}

Drug abusers share needles/ syringes among them, to inject drugs like morphine, cocaine and heroin into their bodies. This activity of sharing needles/ syringes may share HBV among them. In the drug abusers of Quetta (Balochistan), who inject drugs by shared injections, $6 \%$ seroprevalence was observed [69]. A higher (3.2\%) prevalence rate of HBV in needlesharing drug addicts was found in Iran as compared to $1.7 \%$ in the general public [70].

\section{Conclusion}

The current study indicates a relatively higher hepatitis B virus prevalence of in the general populace of district Lakki Marwat and the disease flourishes more in males than females and in the young age peoples. A universal free vaccination program and a quick fruitful crackdown against the medical quacks is required on urgent basis to stunt the spread of HBV. Social media activists, local journalists and Islamic scholars/Ulama should play their role in educating the general public about this havoc. An integrated disease management is required to overcome the problem of hepatitis B in the study area.

\section{Authors' contributions}

Conceived and designed the experiments: ZUR Awan \& MI Shah, Performed the experiments: MI Shah, Analyzed the data: ZUR Awan, Contributed materials/ analysis/ tools: ZUR Awan \& MI Shah, Wrote the paper: MI Shah \& ZUR Awan.

\section{References}

1. Purcell RH (1994). Hepatitis viruses: changing patterns of human disease. Proc Nati Acad Sci 91(7): 2401-2404.

2. Linnen J, Wages J, Zhang-Keck ZY, Fry KE, Krawczynski KZ, Alter H, Koonin E, Gallagher M, Alter M, Hadziyannis S, \& Karayiannis $\mathrm{P}$ (1996). Molecular cloning and disease association of hepatitis $G$ virus: a transfusion-transmissible agent. Sci 271(5248): 505-508.

3. Matsuura K, Tanaka Y, Hige S, Yamada G, Murawaki Y, Komatsu M, Kuramitsu T, Kawata S, Tanaka E, Izumi N \& Okuse C (2009). Distribution of hepatitis B virus genotypes among patients with chronic infection in Japan shifting $\mathrm{J}$ toward an increase of genotype A. J Clin Microbiol 47(5): 1476-1483.

4. Tatematsu K, Tanaka Y, Kurbanov F, Sugauchi F, Mano S, Maeshiro T, Nakayoshi T, Wakuta M, Miyakawa Y\& Mizokami M (2009). A genetic 
variant of hepatitis B virus divergent from known human and ape genotypes isolated from a Japanese patient and provisionally assigned to new genotype. J Virol 83(20): 1053810547.

5. Paraskevis D, Magiorkinis G, Magiorkinis E, Ho SY, Belshaw R, Allain JP \& Hatzakis A (2013). Dating the origin and dispersal of hepatitis $\mathrm{B}$ virus infection in humans and primates. Hepatol 57(3): 908-916.

6. Littlejohn M, Locarnini S \& Yuen L (2016). Origins and evolution of hepatitis B virus and hepatitis D virus. CSH Perspect Med 6(1): a021360.

7. Mühlemann B, Jones TC, de Barros, Damgaard P, Allentoft ME, Shevnina I, Logvin A, Usmanova E, Panyushkina IP, Boldgiv B, Bazartseren T \& Tashbaeva K (2018). Ancient hepatitis $\mathrm{B}$ viruses from the Bronze Age to the Medieval period. Nature 557(7705): 418-423.

8. Ross ZP, Klunk J, Fornaciari G, Giuffra V, Duchêne S, Duggan AT, Poinar D, Douglas MW, Eden JS, Holmes EC \& Poinar HN (2018). The paradox of $\mathrm{HBV}$ evolution as revealed from a 16th century mummy. PLoS Pathog 14(1): e1006750.

9. Lin CL \& Kao JH (2015). Hepatitis B virus genotypes and variants. $\mathrm{CSH}$ Perspect Med 5: a021436.

10. Ali M, Idrees M, Ali L, Hussain A, Rehman IU, Saleem S, Afzal S \& Butt S (2011). Hepatitis B virus in Pakistan: a systematic review of prevalence, risk factors, awareness status and genotypes. Virol J 8(1):102.

11. Harris BJ, Holzmayer V, Qureshi H, Khan MA, Khan SA, Salamat N, Jafri S \& Brennan CA (2017). Hepatitis B genotypes and surface antigen mutants present in Pakistani blood donors. PloS One 12(6): e0178988.

12. Awan ZU, Shah AH \& Kahan S (2017). Molecular Epidemiology and Characterization of Hepatitis B Virus (HBV) Genotypes in Chronic HBV
Patients of Khyber Pakhtunkhwa, Pakistan. Transylvanian Rev 1(1).

13. Bangash $\mathrm{MH}$, Bangash $\mathrm{TH} \&$ Alam $\mathrm{S}$ (2009). Prevalence of hepatitis B and hepatitis $\mathrm{C}$ among healthy blood donors at Kurram agency. J Postgrad Med 23(2): 140-145.

14. Census Report of Pakistan (2017). Pakistan Bureau of Statistics, G-9/1, Islamabad-Pakistan.

http://www.pbs.gov.pk/content/popula tion-census.

15. Human Development Index Reports (2016). UNDP. http://www.hdr.undp.org/en.

16. Hepatitis B Foundation, USA (2019). 3805 Old Easton Road Doylestown, PA 18902- USA. http://www.hepb.org.

17. Blumberg BS (1977). Australia antigen and the biology of hepatitis B. Sci 197(4298): 17-25.

18. Alter HJ (1981). Hepatitis B: a tribute to nondirected medical research. In Semin Liver Dis 1(01): 2-6.

19. Malik IA (1987). Clinicopathological study of viral hepatitis. Pak J Med Res 26: 4-11.

20. Tariq WV, Ahmed M \& Fazal I (1991). Hepatitis B virus problem in Pathology Laboratory. In VII Int Cong of Pak Soc of Gastroen \& GI Endoscopy. Handbook of the Congress Peshawar.

21. District Government Lakki Marwat (2018). Lakki Marwat-Health Facilities. http://Lakki Marwat.gkp.pk.

22. District Census Report of Lakki Marwat-1998 (2000). Pakistan Bureau of Statistics, Population Census organization, Statistical Division, Government of Pakistan. Pg-23. http://121.52.153.178:8080/xmlui/han dle/123456789/14729.

23. Census Report of Lakki Marwat (2017). Pakistan Bureau of Statistics, G-9/1, Islamabad, Pakistan. http://www.pbscensus.gov.pk.

24. Hayder I, Ahmed W \& Alam SE (2012). Comparison of Different ICT Kits for HBsAg and Anti HCV Using Gold Standard ELISA. Paki J Med Res 
51(3): 72-76.

25. Alam MM, Zaidi SZ, Malik SA, Naeem A, Shaukat S, Sharif S, Angez M, Khan A \& Butt JA (2007). Serology based disease status of Pakistani population infected with Hepatitis B virus. BMC Infect Dis 7(1): 1-4.

26. Nafees $M$, Farooq $M$ \& Jafferi $G$ (2009). Frequency of hepatitis B and C infections in the general population of Lahore, Pakistan. Biomed 25: 106-11.

27. Qureshi H, Bile KM, Jooma R, Alam SE \& Afridi HU (2010). Prevalence of hepatitis B and $C$ viral infections in Pakistan: findings of a national survey appealing for effective prevention and control measures. E Mediterr Health J 16 (Supp): 15-23.

28. Khan F, Akbar H, Idrees M, Khan H, Shahzad K \& Kayani MA (2011). The prevalence of $\mathrm{HBV}$ infection in the cohort of IDPs of war against terrorism in Malakand Division of Northern Pakistan. BMC Infect Dis 11(1): 1-6.

29. Khan F, Shams S, Qureshi ID, Israr M, Khan H, Sarwar MT \& Ilyas M (2011). Hepatitis B virus infection among different sex and age groups in Pakistani Punjab. Virol J 8(1): 225.

30. Daud M, Hassan A, Ahmad A, Ali F, Khan MA \& Rehman MU (2015). Prevalence of Hepatitis B and C Infection in District Dir, Khyber Paktunkhwa, Pakistan. World J Zool 10(2): 142-146.

31. Aslam MN, Nadeem M \& Qureshi UF (2016). Hepatitis B and C. TPMJ 23(1): 25-28.

32. Hussain S \& Ali Z (2016). Prevalence of hepatitis B virus in the Kurram Agency, Pakistan: A 5-year observational study in a war-affected region. J Clin Virol 82: 17-19.

33. Ahmad F, Rehman MU, Jadoon MA, Hayat A, Khan I \& Ullah R (2017). Prevalence of Hepatitis B and C Infection in Havelian City, Khyber: Pakhtunkhwa, Pakistan. J Ent Zool Stud 5: 1024-1026.

34. Israr M, Ali F, Muhammad M \&
Bahadar N (2017). Seroprevalence and risk factors of hepatitis $\mathrm{B}$ virus among blood donors in district Charsadda Khyber Pakhtunkhwa Pakistan. Pure Appl Biol 6(2): 669-675.

35. Najib R, Mumtaz S, Ahmed J, Muhammad H, Ahmed N \& Qureshi MS (2017). Frequency of hepatitis B, hepatitis $\mathrm{C}$ and human immunodeficiency viruses in internally displaced persons of South Waziristan. Pak J Postgrad Med Inst 31(1): 82.

36. Quddus A, Luby SP, Jamal Z \& Jafar T (2006). Prevalence of hepatitis B among Afghan refugees living in Balochistan, Pakistan. Int J Infect Dis 10(3): 242-247.

37. Khan MI \& Muhammad M (2012). Frequency of hepatitis B and C in patients visiting outpatient department of district headquarters hospital Lakki. J Postgrad Med Inst 26(1): 55-60.

38. Ahmad A, Ahmad B, Ali A \& Ahmad Y (2009). Seroprevalence of HBsAg and anti-HCV in general healthy population of Swat district with frequency of different $\mathrm{HCV}$ Genotypes. Pak J Med Sci 25(5): 744748.

39. Khattak AM, Nawaz HA, Khan J \& Khan H (2012). Frequency of hepatitis $\mathrm{B}$ and $\mathrm{C}$ on screening in Dera Ismail Khan. Gomal J Med Sci 10(1): 84.

40. Majid A, Khan MS \& Ullah S (2010). Rising prevalence of hepatitis $\mathrm{B}$ and $\mathrm{C}$ and risk factors at district headquarter teaching hospital Bannu, Khyber Pakhtunkhwa. J Coll Phys Surg Pak 20(7): 492-493.

41. Rahim F, Khan M, Rehman HU, Khan MI, Ud H, Din MZ, Khan T, Khan F, Ahmad W, Mahmood N \& Ullah K (2019). Prevalence of Hepatitis B and $C$ virus infection in IDP's Camp of North Waziristan Agency and FRBakakhel of Khyber Pakhtunkhwa, Pakistan. Int J Biosci 14(3): 237-242.

42. Khan AJ, Luby SP, Fikree F, Karim A, Obaid S, Dellawala S, Mirza S, Malik $\mathrm{T}$, Fisher-Hoch S \& McCormick JB 
(2000). Unsafe injections and the transmission of hepatitis $\mathrm{B}$ and $\mathrm{C}$ in a periurban community in Pakistan. $B$ World Health Organ 78(1): 956-963.

43. Usman HR, Akhtar S, Rahbar MH, Hamid S, Moattar $T$ \& Luby SP (2003). Injections in health care settings: a risk factor for acute hepatitis B virus infection in Karachi, Pakistan. Epidemiol Infect 130(2): 293-300.

44. Woods R (1984). Prevention of transmission of hepatitis B in dental practice. Int Dent J 4(2): 122-126.

45. Dahiya $P$, Kamal R, Sharma V \& Kaur $S$ (2015). Hepatitis"-Prevention and management in dental practice. $J E d u$ Health Promot 4(1): 33.

46. Janjua NZ \& Nizamy MA (2004). Knowledge and practices of barbers about hepatitis B and $\mathrm{C}$ transmission in Rawalpindi and Islamabad. J Pak Med Assoc 54(3): 116-118.

47. Luby S, Khanani R, Zia M, Vellani Z, Ali M, Qureshi AH, Khan AJ, Mujeeb SA, Shah SA \& Fisher-Hoch S (2000). Evaluation of blood bank practices in Karachi, Pakistan, and the government's response. Health Pol Plann 15(2): 217-222.

48. Ahmed M (2001). Hepatitis B surface antigen study in professional and volunteer blood donors. Ann Abbassi Shaheed Hosp Karachi Med Dent Coll 6: 304-306.

49. Stevens CE, Beasley RP, Tsui J \& Lee WC (1975). Vertical transmission of hepatitis B antigen in Taiwan. N Engl J Med 292(15): 771-774.

50. Zervou EK, Gatselis NK, Xanthi E, Ziciadis K, Georgiadou SP \& Dalekos GN (2005). Intrafamilial spread of hepatitis B virus infection in Greece. Eur J Gastroen Hepat 17(9): 911-915.

51. Lobato C, Tavares- Neto J, RiosLeite M, Trepo C, Vitvitski L, Parvaz P, Zoulim F, D’Oliveira Jr A \& Paraná $R$ (2006). Intrafamilial prevalence of hepatitis B virus in Western Brazilian Amazon region: epidemiologic and biomolecular study. J Gastroenterol
Hepatol 21(5): 863-868.

52. Heng BH, Goh KT, Chan R, Chew SK, Doraisingham S \& Quek GH (1995). Prevalence of hepatitis B virus (HBV) infection in Singapore men with sexually transmitted diseases and HIV infection: role of sexual transmission in a city state with intermediate HBV endemicity. J Epidemiol Community Health 49(3): 309-313.

53. Shao ZJ, Xu DZ, Xu JQ, Li JH, Yan YP, Men K, Wang XP, Zhang ZY, Jiang QW \& Zhang L (2007). Maternal hepatitis $B$ virus (HBV) DNA positivity and sexual intercourse are associated with HBV intrauterine transmission in China: a prospective case-control study. J Gastroenterol Hepatol 22(2): 165-170.

54. Todd CS, Nasir A, Stanekzai MR, Bautista CT, Botros BA, Scott PT, Strathdee SA \& Tjaden J (2010). HIV, hepatitis B and hepatitis $\mathrm{C}$ prevalence and associated risk behaviors among female sex workers in three Afghan cities. AIDS (London, England) 24(2): S69-S75.

55. Franco E, Bagnato B, Marino MG, Meleleo C, Serino L \& Zaratti L (2012). Hepatitis B: Epidemiology and prevention in developing countries. World J Hepatol 4(3): 74.

56. Hadler SC, Doto IL, Maynard JE, Smith J, Clark B, Mosley J, Eickhoff T, Himmelsbach CK \& Cole WR (1985). Occupational risk of hepatitis B infection in hospital workers. Infection Control 6(1): 24-31.

57. Petrosillo N, Puro V, Jagger J \& Ippolito $G$ (1995). The risks of occupational exposure and infection by human immunodeficiency virus, hepatitis $\mathrm{B}$ virus, and hepatitis $\mathrm{C}$ virus in the dialysis setting. Am J Infect Control 23(5): 278-285.

58. Shapiro CN (1995). Occupational risk of infection with hepatitis B and hepatitis C virus. Surg Clin N Am 75(6): 1047-1056.

59. Talaat M, Kandeel A, El-Shoubary W, 
Bodenschatz C, Khairy I, Oun S \& Mahoney FJ (2003). Occupational exposure to needlestick injuries and hepatitis $B$ vaccination coverage among health care workers in Egypt. Am J Infect Control 31(8): 469-474.

60. Inciardi JA, Surratt HL \& Kurtz SP (2006). HIV, HBV and HCV infections among drug-involved, inner-city, street sex workers in Miami, Florida. AIDS and Behavior 10(2): 139-147.

61. Forbi JC, Onyemauwa N, Gyar SD, Oyeleye AO, Entonu P \& Agwale SM (2008). High prevalence of hepatitis B virus among female sex workers in Nigeria. Revista do Instituto de Medicina. Tropical de São Paulo 50(4): 219-221.

62. Attaullah S, ur Rehman S, Khan S, Ali I, Ali S \& Khan SN (2011). Prevalence of Hepatitis B virus genotypes in HBsAg positive individuals of Afghanistan. Virol J 8(1): 281.

63. Anwar MS, Jaffery G \& Rasheed A (1998). Serological screening of female prostitutes for anti-HIV and hepatitis B surface antigen. Pak $J$ Health 35(3-4): 69-73.

64. Sebastian VJ, Ray S, Bhattacharya S, Maung OT, Saini HM \& Jalani HD (1992). Tattooing and hepatitis B infection. $J$ Gastroenterol Hepatol 7(4): 385-387.
65. Nishioka SD \& Gyorkos TW (2001). Tattoos as risk factors for transfusiontransmitted diseases. Int $J$ Infect Dis 5(1): 27-34.

66. Samuel MC, Doherty PM, Bulterys M \& Jenison SA (2001). Association between heroin use, needle sharing and tattoos received in prison with hepatitis $\mathrm{B}$ and $\mathrm{C}$ positivity among streetrecruited injecting drug users in New Mexico, USA. Epidemiol Infect 127(3): 475-484.

67. Aweis D, Brabin BJ, Beeching NJ, Bunn JE, Cooper C, Gardner K, Iriyagolle C \& Hart CA (2001). Hepatitis B prevalence and risk factors for HBsAg carriage amongst Somali households in Liverpool. Commun Dis Public Health 4(4): 247-252.

68. Mousa HA (2015). Transmission of Bloodborne Infections by Circumcision Procedure. J Infect Dis Ther 3: e107.

69. Achakzai M, Kassi M \& Kasi PM (2007). Seroprevalences and coinfections of HIV, hepatitis $\mathrm{C}$ virus and hepatitis $\mathrm{B}$ virus in injecting drug users in Quetta, Pakistan. Trop Doct 37(1): 43-45.

70. Poorolajal J \& Majdzadeh R (2009). Prevalence of chronic hepatitis $\mathrm{B}$ infection in Iran: a review article. $J$ Res Med Sci 14(4): 249. 